\title{
'Mountain Vineyard' Hybrid Grape Tomato and Its Parents: NC 4 Grape and NC 5 Grape Tomato Breeding Lines
}

\section{Dilip R. Panthee ${ }^{1}$ and Randy G. Gardner Department of Horticultural Science, North Carolina State University, Mountain Horticultural Crops Research and Extension Center (MHCREC), 455 Research Drive, Mills River, NC 28759-3423}

Additional index words. $b r$ gene, crimson $\left(o g^{c}\right)$ gene, disease resistance, $I-3$ gene, male sterility, $m s-10$ gene, $S w-5$ gene, total soluble solids

'Mountain Vineyard' is a hybrid grape tomato (Solanum lycopersicum $\mathrm{L}$.) resulting from the cross of NC 4 grape $\times$ NC 5 grape. It has a compact, indeterminate growth habit with short internodes conferred by the brachytic gene $(b r)$. It is heterozygous for the $I-3$ gene for resistance to fusarium wilt race 3 [Fusarium oxysporum f.sp. lycopersici (Sacc.) Snyd. and Hans.] and the $S w-5$ gene for resistance to Tomato spotted wilt virus (TSWV). Fruits are high in soluble solids with an attractive deep red color resulting from the recessive crimson gene $\left(B c\right.$ or $\left.o g^{c}\right)$ in homozygous condition.

\section{Origin}

'Mountain Vineyard' (tested as NC 10235) is the culmination of a tomato breeding effort initiated in 2002 to develop a superior hybrid grape tomato comparable to the highly successful 'Smarty' hybrid (NC 3 grape $\times$ NC 2 grape) in horticultural traits with improved fruit color resulting from the crimson ( $B c$ or $\left.o g^{c}\right)$ gene combined with fusarium wilt race 3 and TSWV resistances.

NC 4 grape shares the $S w-5$ gene for TSWV and the $I-3$ gene for fusarium wilt race 3 resistances, which were derived from the large, round-fruited hybrid 'Amelia' codeveloped by North Carolina State University and Clause Seed Co. A cross was made in the greenhouse in Fall 2002 between an $\mathrm{F}_{4}$ generation inbred line homozygous for $S w-5$ and I-3 developed by selfing 'Amelia' (Fig. 1) and the plum tomato breeding line NC EBR-7 (Gardner, 2006). This $\mathrm{F}_{1}$ hybrid, 034, was selfed to produce a plum tomato line, 034 (x)69-1, which is homozygous for $\mathrm{Sw}-5$ and $I-3$ as determined by molecular markers closely linked to the two genes. The 034 selfed line

Received for publication 10 Apr. 2013. Accepted for publication $1 \mathrm{Aug} .2013$.

The tomato breeding program of North Carolina State University is supported by the North Carolina Tomato Growers Association and the Hatch project of the USDA.

${ }^{1}$ To whom reprint requests should be addressed; e-mail Dilip_panthee@ncsu.edu. was crossed to NC 2 grape (Gardner and Panthee, 2010a) to develop the $F_{1}$ hybrid 0579 , which was selfed to develop the $F_{4}$ generation inbred line, 0579 (x)-43-7-4, a large tomato breeding lines. grape-type tomato with a compact indeterminate growth habit and short internodes resulting from the $b r$ gene derived from NC 2 Grape (Gardner and Panthee, 2010a). The 0579 line tested homozygous-resistant for $\mathrm{S} w-5$ and $I-3$ using molecular marker-assisted selection.

The determinate ( $s p$ gene) grape tomato line NC 3 grape (Gardner and Panthee, 2010a) was used as the source of the crimson gene $\left(o g^{c}\right)$ and the $m s-10$ male sterile gene linked to the anthocyanin absent $(a a)$ seedling marker gene in NC 4 grape (Fig. 1). A crimson, $m s$ 10aa determinate $\mathrm{F}_{3}$ selection [032 (x)-5-11 gsms] from the cross of NC 3 grape with another determinate, crimson grape tomato line, was crossed to NC 2 grape, and 2000 plants from the $F_{2}$ generation of this cross (042) were grown to flowering in the greenhouse. A large $F_{2}$ population was needed to break the very tight linkage, reported as one crossover unit of the $\operatorname{og}^{c}$ ( or $B c$ ) gene to the $s p$ gene for determinate growth habit (Mutschler et al., 1987). The recessive crimson

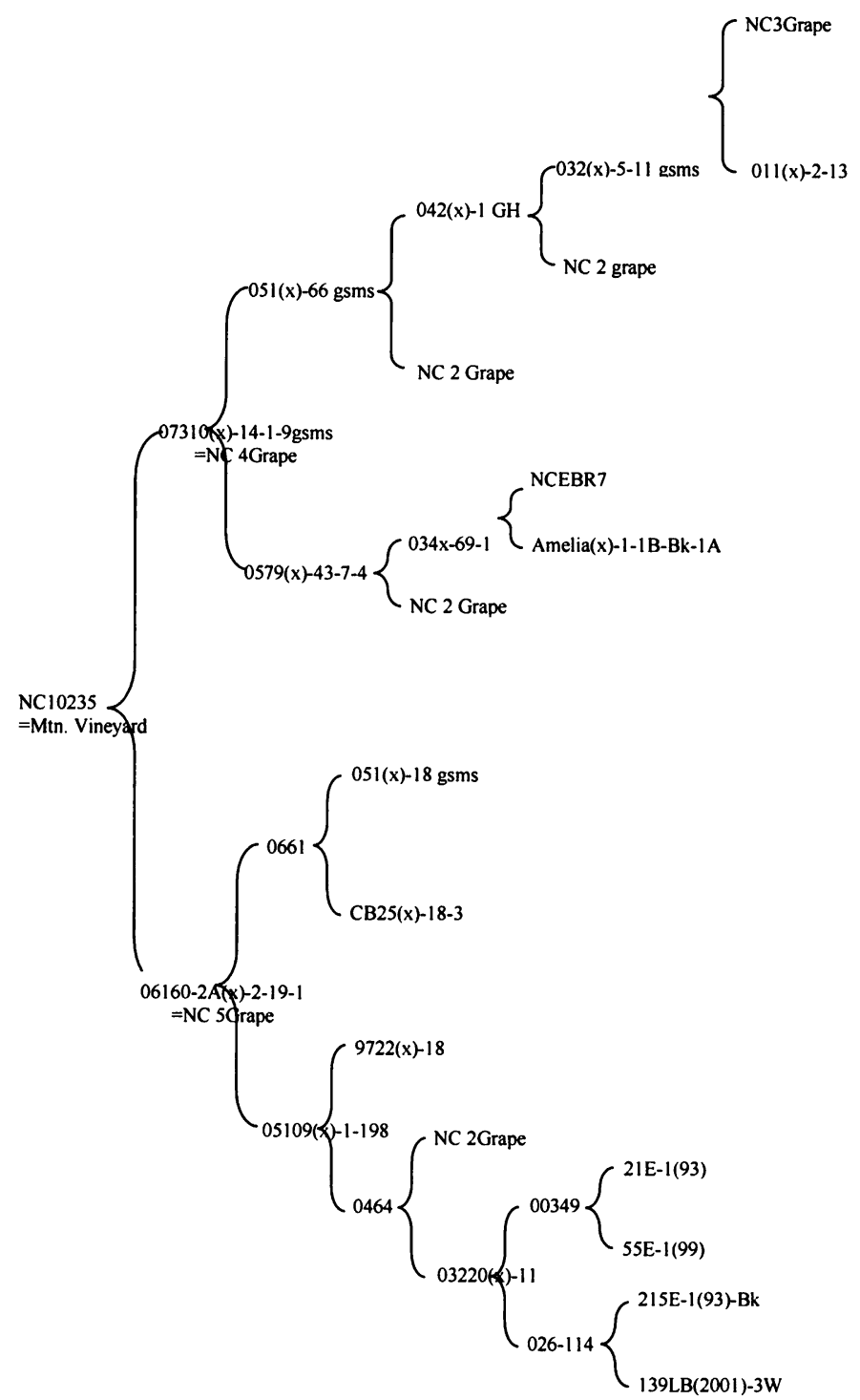

Fig. 1. Pedigree of 'Mountain Vineyard' hybrid grape tomato and its parents, NC 4 grape and NC 5 grape 
gene segregates in the $\mathrm{F}_{2}$ population $(\approx 500$ plants) were saved based on the distinctive dark, golden yellow stripes on the flower petals when $0 g^{c}$ is present in a homozygous condition. Plants with the ${ }^{\circ} g^{c}$ flower color were grown until determination could be made for indeterminate vs. determinate growth habit by number of leaves between flower clusters, three for indeterminate and less than three for determinate. The indeterminate, crimson $\mathrm{F}_{2}$ selection 042 (x)-1GH was crossed to NC 2 grape, and an $\mathrm{F}_{2}$ selection from this cross, 051 (x)-66gsms, that was homozygous for the ${ }^{c} g^{c}$ gene linked to indeterminate growth and carrying the $m s-10, a a$ gene combination was used in further crossing.

The cross of 051 (x)-66 gsms $\times 0579$ (x)43-7-4 produced the $\mathrm{F}_{1}$ hybrid 07310. A population of 192 plants in the $F_{2}$ generation of 07310 was grown in the greenhouse and selected for desirable plant and fruit traits. The subsequent $F_{3}$ brachytic, indeterminate selection $07310(\mathrm{x})-14-1$, outstanding in plant and fruit type, was homozygous for $o^{c}$, heterozygous for the $m s-10$, a a combination, and homozygous for both $S w-5$ and $I-3$ as determined by molecular markers tightly linked to the two disease resistance genes. The $\mathrm{F}_{4}$ selection $07310(\mathrm{x})-14-1-9$ was made from the field in 2009 based on desirable horticultural traits. It segregated for the $m s-$ 10, a a gene combination and homozygous for $\operatorname{og}^{c}$ and continued to test homozygous for $S w-5$ and $I-3$ genes according to tightly linked molecular markers (Fig. 2). Seed of this $F_{4}$ selection were bulked in $F_{5}$ selfed generation, and it is being released as NC 4 grape.

NC 5 grape shares some of the same pedigree as NC 4 grape up to the 051 hybrid (Fig. 1). An $\mathrm{F}_{2}$ selection from this cross, 051 (x)-18 gsms, that was homozygous for the ${ }^{c} g^{c}$ gene linked to indeterminate growth was crossed to CB 25 (x)-18-3, an $\mathrm{F}_{3}$ indeterminate, brachytic, high sugar tomato line resulting from selfing the CB $25\left(\mathrm{~F}_{1}\right.$ hybrid of a Clause proprietary cherry tomato line $\times \mathrm{NC}$ 1 grape) to produce the $0661 \mathrm{~F}_{1}$ hybrid.

For the pedigree leading to NC 5 grape, NC 2 grape was crossed in the greenhouse in the fall of 2003 to the large, round-fruited early blight/late blight-resistant line 03220 (x)-11 to produce the $\mathrm{F}_{1}$ hybrid 0464 . The 03220 hybrid was also selfed to develop the early blight/ late blight-resistant breeding lines $\mathrm{NC}$ 1CELBR and NC 2CELBR (Gardner and Panthee, 2010b). The 0464 hybrid was then crossed with 9722 (x)-18, an early blight/late blight-resistant $F_{2}$ cherry tomato selection derived from backcrossing the $P h-3$ gene for late blight resistance from the $S$. pimpinellifolium L 3707 selection into the early blightresistant line 215E-1 (93). The resultant $\mathrm{F}_{1}$ hybrid, 05109, was selfed, grown in the field in the $F_{2}$ generation, and selected for late blight resistance and horticultural traits. The $\mathrm{F}_{3}$ generation line was then grown in the greenhouse, and 05109 (x)-1-198, a high sugar cherry tomato selection, was identified as late blight-resistant by a detached leaf inoculation technique.
NC0661 was crossed with 05109(x)-1198 to produce the $F_{1}$ hybrid 06160 . A single $\mathrm{F}_{1}$ plant selection from this cross, 06160-2A, was selfed, and the $\mathrm{F}_{2}$ generation was grown in the field in 2007 to produce the outstanding crimson, compact indeterminate, brachytic grape tomato selection 06160-2A(x)-2. Subsequent selfing and selection in the greenhouse and field led to the $\mathrm{F}_{4}$ generation line 06160-2A(x)-2-19-1, of which seed were bulked in selfed generations beyond the $\mathrm{F}_{4}$ for release as NC 5 grape.

\section{Description}

'Mountain Vineyard' is the first known indeterminate grape tomato hybrid with the homozygous recessive crimson $\left(o g^{c}\right)$ gene for improved red fruit color and increased lycopene content. It has short internodes conferred by the brachytic $(b r)$ gene. Foliage is dark green in color and provides good cover for the fruit. Immature fruits have a glossy finish with dark green shoulders. Fruit of 'Mountain
Vineyard' develop a deep red color resulting from the crimson gene and are firm in the fully ripened stage. Fruit pedicels are jointed ( $\mathrm{J} 2$ gene), and the fruit separate easily from the pedicels during harvest. The fruit are long and ovate in shape and have good resistance to fruit cracking and bursting.

Yield and quality of 'Mountain Vineyard' was compared with 'Smarty', a hybrid with very similar plant and fruit type. When averaged over four field trials with three replications each conducted during the summer seasons of 2010-12, 'Mountain Vineyard' was lower than 'Smarty' for total and marketable yields and percent soluble solids. However, marketable yield (\%) of 'Mountain Vineyard' was significantly higher than 'Smarty' (Table 1). Average fruit size did not differ for the two cultivars.

'Mountain Vineyard' has received good taste test reviews and grown well in numerous observational trials in research station and growers' fields in western North Carolina and the coastal area of South Carolina. Flavor

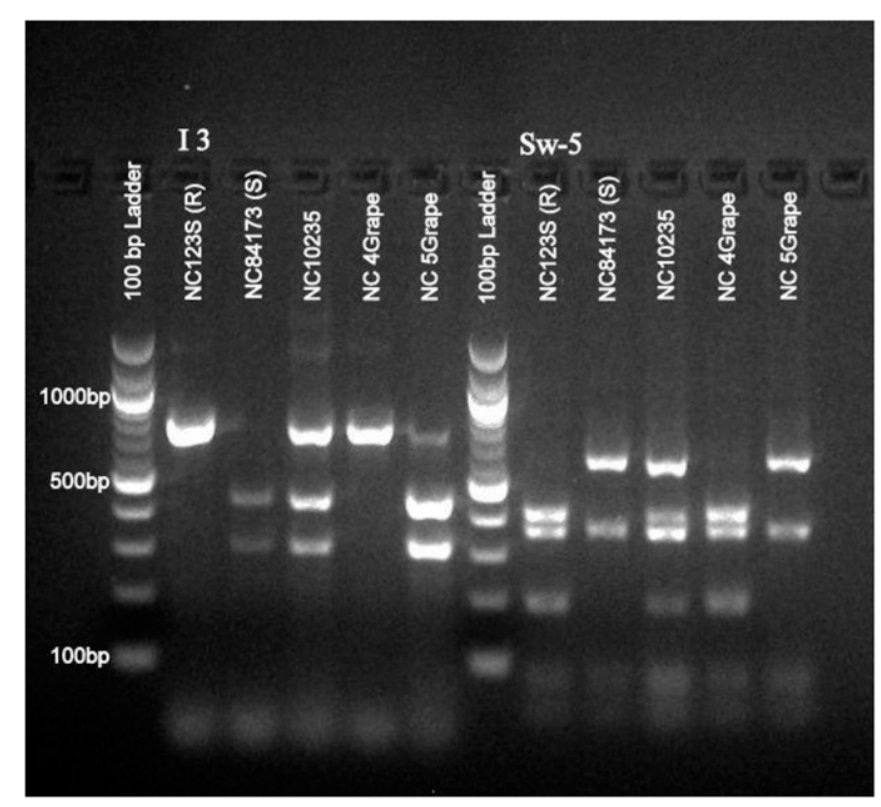

Fig. 2. Molecular markers analysis for fusarium wilt race 3 resistance conferred by $I-3$ gene (left panel) and Tomato spotted wilt virus resistance conferred by $S_{w}-5$ gene (right panel separated by DNA ladder) in NC10235 ('Mountain Vineyard'), NC 4 grape, and NC 5 grape breeding lines. NC 123S and NC 84173 were used as resistant and susceptible controls, respectively. Molecular markers associated with $I-3$ (TG217) and $S w-5$ (NCSw-011) are cleaved amplified polymorphic sequence (CAPS) type (Panthee and Ibrahem, 2013)

Table 1. Average yield, fruit size, and total soluble solids of NC 5 grape tomato and the $\mathrm{F}_{1}$ hybrid 'Mountain Vineyard' (NC 4 grape $\times$ NC 5 grape) compared with the control $F_{1}$ hybrid grape tomato 'Smarty'.

\begin{tabular}{lccccc}
\hline Genotype & $\begin{array}{c}\text { Total yield } \\
\left(\mathrm{t} \cdot \mathrm{ha}^{-1}\right)\end{array}$ & $\begin{array}{c}\text { Marketable yield } \\
\left(\mathrm{t} \cdot \mathrm{ha}^{-1}\right)\end{array}$ & $\begin{array}{c}\text { Marketable } \\
(\%)\end{array}$ & $\begin{array}{c}\text { Fruit } \\
\text { wt }(\mathrm{g})\end{array}$ & $\begin{array}{c}\text { Total soluble } \\
\text { solids (\%) }\end{array}$ \\
\hline Mountain Vineyard & 38.3 & 36.5 & 94.4 & 10.0 & 6.8 \\
Smarty & 43.7 & 41.0 & 91.7 & 9.8 & 7.5 \\
NC 5 grape & 40.1 & 38.0 & 94.8 & 9.3 & 7.1 \\
LSD $_{(0.05)}$ & 3.4 & 3.4 & 1.2 & 1.6 & 0.4 \\
\hline
\end{tabular}

${ }^{2}$ Data are the average of early and late replicated trials in 2010, an early trial in 2011, and late trial in 2012 with three replicates each at the Mountain Horticultural Crops Research and Extension Center, Mills River, NC. Least square means (LSMeans) and least significant difference (LSD) values presented in the table were obtained from analysis of variance performed using SAS software (SAS Institute Inc., 2007).

${ }^{y}$ TSS was measured only in 2010 and 2011. 
and fruit texture of 'Mountain Vineyard' have been rated excellent in subjective taste evaluations in research station plots by growers and consumers. Despite somewhat lower yields and lower percent soluble solids than 'Smarty', 'Mountain Vineyard' was consistently rated as highly promising in research station and grower trials because of its combination of desirable horticultural traits and disease resistances. In grower trials in coastal South Carolina, 'Mountain Vineyard' was free of TSWV symptoms, whereas 'Smarty' was severely affected. Presence of the $S w-5$ gene for TSWV resistance (Panthee and Ibrahem, 2013) and the $I-3$ gene for fusarium wilt race 3 resistance (Barillas et al., 2008) in heterozygous condition was verified by a molecular markers tightly linked to the resistance genes (Fig. 2). In a seedling inoculation trial in a growth chamber, 'Mountain Vineyard' was resistant to fusarium wilt race 3 .

NC 4 grape is a unique tomato breeding line with a desirable combination of disease resistance genes and horticultural traits. It has a compact, indeterminate growth habit with short internodes conditioned by the $b r$ gene and has heavy dark green foliage cover for fruit protection. Fruit average weighs $\approx 10 \mathrm{~g}$. The fruit are a desirable elongate grape tomato shape, develop a deep red interior color as a result of the crimson gene, are crisp in texture with a sweet flavor, and are firm in the fully ripened stage. Ripe fruit have good resistance to bursting and cracking. Immature fruit have a glossy, uniform light green color ( $u$ gene). Fruit pedicels are jointless, and the fruit separate easily from the pedicels at harvest. NC 4 grape is heterozygous for the $m s-10$ male-sterile gene linked to the green stem seedling marker gene $a a$. This allows for selection of male-sterile plants at the seedling stage for use of NC 4 grape as a female parent for making $F_{1}$ hybrids without the need to emasculate flowers or being concerned about self-pollination of the female parent when making crosses. In addition, stigmas are well exerted on male-sterile flowers of NC 4 grape so they are easily accessible for pollen application. NC 4 grape has the $S w-5$ and $I-3$ genes for resistance to TSWV and fusarium wilt race 3 , respectively.
The NC 5 grape tomato breeding line has a vigorous plant with a compact indeterminate growth habit with short internodes conferred by the $b r$ gene. Foliage is an attractive dark green color, providing good coverage for fruit protection and holding up well throughout the season. Immature fruits have a glossy finish with a dark green shoulder color. Fruit pedicels are jointless, and the fruit separate easily from the pedicels at harvest. Fruit of NC 5 grape tomato average $\approx 10 \mathrm{~g}$ and have an ideal elongate shape desired for grape tomatoes. The crimson $\left(o g^{c}\right)$ fruit develop a deep, attractive red color, are crisp in texture with a sweet flavor, and are firm in the fully ripened stage. Fruit maintain good quality on the plant for an extended period after ripening without bursting or cracking. NC 5 grape was susceptible to late blight in a replicated greenhouse disease screen in 2012. NC 4 grape and NC 5 grape have not been tested for other disease resistance genes. However, based on resistances present in parent lines leading to their development, both lines have the potential to have the $V e$ gene for resistance to verticillium wilt and the $I$ gene for resistance to race 1 of fusarium wilt. These lines were not found to have $I-2$ gene conferring resistance to race 2 of fusarium wilt (data not shown).

NC 5 grape was compared in replicated yield trials with 'Smarty'. When averaged over four trials with three replications each at Mountain Horticultural Crops Research Station (MHCRS), NC 5 grape was slightly lower in total yield and total soluble solids, the same in marketable yield and fruit size, and significantly higher in percent marketable grade fruit than 'Smarty' (Table 1).

\section{Use}

'Mountain Vineyard' provides growers in North Carolina and other regions with similar growing conditions a high-yielding, fusarium wilt race 3 and TSWV-resistant grape tomato cultivar with improved fruit color, desirable plant growth habit, and other fruit traits comparable to 'Smarty'. The NC 4 grape and NC 5 grape, both of which have the ${ }^{c} g^{c}$ gene linked to indeterminate growth habit, provide tomato breeders with superior fruit quality and yield potential, which should be useful in breeding and as parents in other $\mathrm{F}_{1}$ hybrids. NC 4 grape should be especially useful because of its combination of the $S w-5, I-3, b r, m s-10$, $a a$, $o g^{c}$, and $j 2$ genes in a breeding line highly adapted for use as a female parent in developing grape tomato hybrids.

\section{Availability}

'Mountain Vineyard' will be licensed to a private seed company on an exclusive basis for seed production and sales. It is expected that commercial seed will be available in 2015. Distribution of seed of NC 4 grape and NC 5 grape to other breeders requires a signed material transfer agreement that can be downloaded at the following web site address: $<$ http://www.ces.ncsu.edu/fletcher/programs/ tomato/releases/tomato-seed-production-andlicense-agreement.pdf $>$. Small trial samples of 'Mountain Vineyard' are available from D.R. Panthee (dilip_panthee@ncsu.edu), MHCREC, 455 Research Drive, Mills River, NC 28759.

\section{Literature Cited}

Barillas, A.C., L. Mejia, A. Sanchez-Perez, and D.P. Maxwell. 2008. CAPS and SCAR markers for detection of $I-3$ gene introgression for resistance to Fusarium oxysporium f.sp. lycopersici race 3. Rpt. Tomato Genet. Coop. 58:11-17.

Gardner, R.G. 2006. 'Plum Crimson' fresh-market plum tomato hybrid and its parents, NC EBR-7 and NC EBR-8. HortScience 41:259-260.

Gardner, R.G. and D.R. Panthee. 2010a. Grape tomato breeding lines: NC 1 Grape, NC 2 Grape, and NC 3 Grape. HortScience 45:18871888.

Gardner, R.G. and D.R. Panthee. 2010b. NC 1 CELBR and NC 2 CELBR: Early blight and late blight-resistant fresh market tomato breeding lines. HortScience 45:975-976.

Mutschler, M., S. Tanksley, and C. Rick. 1987. 1987 linkage maps of the tomato (Lycopersicon esculentum). Rpt. Tomato. Genet. Coop. 37:5-34.

Panthee, D.R. and R. Ibrahem. 2013. New molecular markers associated with the $S w-5$ gene conferring resistance to Tomato spotted wilt virus in tomato. J. Hort. Sci. Biotechnol. 88: 129-134.

SAS Institute Inc. 2007. The SAS System, version 9.1.3 for Windows. SAS Institute, Cary, NC. 